\section{ECONOMICS}

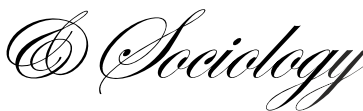

\author{
Brian Micallef, \\ Central Bank of Malta, \\ Valletta, Malta, \\ E-mail: \\ micallefb@centralbankmalta.org
}

Received: May, 2016

1st Revision: September, 2016

Accepted: November, 2016

DOI: $10.14254 / 2071-$

789X.2016/9-4/2

JEL Classification: D24, E24, J24, O47
Micallef, B. (2016), Determinants of Labour Productivity in Malta: Evidence from a Firm-Level Survey, Economics and Sociology, Vol. 9, No 4, pp. 27-40. DOI: 10.14254/2071-789X.2016/9-4/2

\title{
DETERMINANTS OF LABOUR PRODUCTIVITY IN MALTA: EVIDENCE FROM A FIRM-LEVEL SURVEY
}

\begin{abstract}
Labour productivity in Malta has been sluggish after the crisis. This study looks at the determinants of productivity in Malta by exploiting information from a unique firm-level survey using an empirical multivariate framework. Labour productivity is more likely to be lower in firms with a higher labour share, suggesting that the significant shift towards labourintensive services observed in recent years is likely to be an important driver behind the slowdown in productivity. Outsourcing and the characteristics of the workforce are also important determinants. On the contrary, credit constrained firms and those hit by adverse demand conditions are less likely to experience an improvement in productivity.
\end{abstract}

Keywords: productivity, firm survey, Malta.

\section{Introduction}

The Maltese economy has been one of the best performing members of the euro area after the global financial crisis. Growth has been job-rich with the increase in employment after the crisis being four times higher than that achieved in the decade before the crisis. The resilience of the Maltese economy is attributed to a more diversified economic base, which since around EU membership in 2004 has gradually shifted from traditional activities towards higher-value added ones, mostly in services.

Labour productivity, however, has been sluggish after the crisis, underperforming most other European economies (Micallef, 2015). In addition, the absence of sectoral price deflators renders an in-depth analysis of sectoral productivity particularly challenging at a time when it is being increasingly recognised that economy-wide measures of productivity have to be complemented by sectoral and, if available, firm-level developments (Di Mauro and Ronchi, 2015).

The changing structure of the Maltese economy further complicates the analysis of productivity. The main sectors generating growth since EU membership have similar value added multipliers compared to those in the previous decade but much higher employment multipliers. Grech (2015) argues that the expansion of these labour-intensive services industries has played a key role in the slowdown of Malta's apparent productivity in recent years and the associated rise in unit labour costs, despite moderate increases in wage growth. 
These trends complicate the assessment of competitiveness using aggregate measures of unit labour costs.

This paper adds to the empirical literature on productivity in Malta by exploiting information from a unique firm-level survey carried out by the Central Bank of Malta in 2014 as part of the Wage Dynamics Network (WDN) project. Such a survey provides rich evidence, directly from firms, with a detailed breakdown by sector and size classes that are not available from existing statistics. Using this dataset, developments in labour productivity compared to costs are investigated within an empirical multivariate framework that controls for the firm's characteristics (such as size and sector of activity), production technology, the characteristics of the workforce, restructuring efforts, exposure to foreign markets, as well as the nature of shocks hitting the firm. To the best of my knowledge, this is the first study that looks at the determinants of labour productivity in Malta by using survey information to fill the gap imposed by severe data limitations, both at a micro and macro level.

The main results are summarized as follows. Labour productivity is more likely to be lower in firms with a higher share of labour in total costs, thus confirming that the significant shift towards more labour-intensive services observed in recent years is likely to be an important driver behind the slowdown in productivity. Firms implementing changes to their production structure by out-sourcing part of their operations are more likely to experience an improvement in productivity. The characteristics of the workforce, such as a higher share of skilled workers and workforce stability, are positively related to productivity. On the contrary, credit constrained firms are less likely to experience an improvement in productivity. Adverse demand shocks are negatively related to labour productivity, possibly due to labour hoarding, although this result is not robust across the various model specifications.

The rest of the paper is organised as follows. Section 2 provides a brief review of the literature on the main determinants of productivity. Section 3 gives an overview of the WDN survey. Section 4 looks at the survey results on productivity, focusing in particular on the empirical model. A discussion of the results and some policy recommendations are found in section 5. Section 6 concludes.

\section{Literature review}

There is a broad consensus among economists that productivity plays a key role in economic success and is the main driver of per capita growth in the long-run (Krugman, 1994; Hall and Jones, 1999). The exact determinants of productivity, however, still elude the profession. ${ }^{1}$ The voluminous literature in this area can be broadly classified into micro, sectoral and macroeconomic cross-country studies.

In the neo-classical growth model, labour productivity depends on total factor productivity (TFP) and capital deepening (Solow, 1957). Within this class of models, improvements in TFP growth or technological progress are the key determinant of long-run growth although it does not seek to explain it. Modern growth theories, which seek to explain TFP within the model, points to the importance of innovation, such as investment in research and development (R\&D), in driving productivity growth (Romer, 2000; Barro and Sala-iMartin, 2004).

\footnotetext{
${ }^{1}$ In addition, projections about future productivity growth are equally controversial. Gordon (2016) argues that productivity growth in the US has been slowing down since the 1970s and that future productivity growth will be lower than those observed in the past as the current round of innovations in areas such as healthcare and ICT are less transformative than those of the late nineteenth century, such as electricity and the internal combustion engine. Clark (2016) and Fernald (2012) are also pessimistic about future TFP growth. On the contrary, studies such as Bartelsman (2013) and Brynjolfsson and McAfee (2014) point to ICT as the driving force of future productivity gains.
} 
Studies on the determinants of productivity in Malta are relatively scarce mostly due to data limitations, such as the absence of sectoral price deflators. The two studies on this topic use an aggregate and a firm-level approach, respectively. Using a production function approach, Grech and Micallef (2015) observed a trend decline in the contribution of total factor productivity (TFP) to potential output growth. Micallef (2015) uses firm level data and finds that the productivity distribution is not only dispersed but also very asymmetric, featuring a large mass of low productive firms and very few high productive ones. Neither study, however, looks into the determinants of productivity.

The literature has identified a broad set of factors that explain cross-country differences in productivity or TFP growth. In these studies, macroeconomic and institutional factors, trade openness and policies that enhance the quality of human and capital stock are commonly found to play an important role in raising productivity growth (Barro, 2001; European Commission, 2014). For instance, a number of studies find that a skilled workforce tend to promote innovation, which, in turn, raises productivity (Sondermann, 2012). Similarly, investment in information and communication technology (ICT) and on R\&D is commonly found to play a crucial role in explaining productivity performance (Griffith et al., 2004). In terms of institutions, the literature suggests that productivity tends to be weaker in countries with rigid product and labour markets, since these rigidities may hamper the adoption of new technologies or delay firm-level adjustment (Nicoletti and Scarpetta, 2003). Other studies point to the role of a well-functioning financial system in driving growth and productivity by facilitating the allocation of savings to investment opportunities (Hartmann et al., 2007).

Turning to the micro evidence, studies point to large differences in productivity among firms even within narrowly defined industries (Bartelsman and Doms, 2000; Bartelsman et al., 2009). Using a harmonized cross-country firm-level database, the CompNet Task Force (2014) also documents a large degree of heterogeneity in terms of firm productivity and size, both within and across countries. ${ }^{2}$ Productivity distribution tends to be highly skewed across countries, with a small percentage of high productivity firms and thick left tail of low productive ones. This level of disaggregation allows for a more comprehensive assessment of productivity and competitiveness. For instance, Gamberoni et al. (2016) find that aggregate TFP growth is driven both by within-firm efficiency gains and by a more efficient reallocation of resources. Within the latter category, most of the efficiency gains come from reallocation within sectors rather than across sectors. In another study, Altomonte et al. (2011) report that the unit labour costs of firms at the bottom and top decile of the productivity distribution appear to have reacted very differently during and after the crisis.

Studies have also looked at the link between financing constraints and productivity, especially during and after the financial crisis. ${ }^{3}$ Financial market imperfections could amplify financial constraints during a recession due, for instance, to collateral constrains and debt overhang. Ferrando and Ruggieri (2015) find that financial constraints significantly lower productivity in the majority of sectors for a sample of firms in eight euro area countries. Ferrando et al. (2015) report that on average more productive firms are less likely to be credit constrained. These authors also report that during the crisis, the share of credit constrained firms increased more in stressed euro area countries, particularly among the least productive.

In a survey of the literature, Syverson (2010) classified inter-firm differences in productivity in two broad categories. The first set of determinants include factors that operate

\footnotetext{
${ }^{2}$ The database was developed by the Competitiveness Network (CompNet), a research network of the European System of Central Banks. The database comprises a sample of around 700,000 firms per year operating across 58 sectors from 11 countries for the period 1995-2011. See CompNet Task Force (2014) and Lopez-Garcia et al. (2015) for a description of this database and some applications.

${ }^{3}$ A concise survey of the voluminous literature on the link between financing constraints and productivity is available in Ferrando et al. (2015).
} 
within the firm, such as managerial talent, the quality of labour and capital inputs, product innovation and the organisational structure of the firm's production units. The second set of factors refers to environmental determinants, such the productivity spillovers from knowledge transfers, the degree of competition in labour and product markets and the impact of regulation. This category affects productivity by incentivising producers to become more efficient or, alternatively, by shifting economic activity towards more efficient ones.

A number of studies document complementarities between the two categories. For instance, strong competition and flexible labour markets allows firms to adopt better people management practices (Bloom et al., 2012). Multinational firms have a strong positive effect on management practices and their influence is felt throughout the countries in which they operate. Berthou et al. (2015) document that on average exporters are $20 \%$ more productive than non-exporters in the same sector, although there are wide cross-country differences. These authors also find that exports by the largest and most productive firms are less sensitive to exchange rate movements. There is also evidence showing that the elasticity of exports to exchange rate fluctuations is lower in sectors with a higher dispersion of productivity (Demian and di Mauro, 2015).

Higher absorption of ICT is commonly considered to be one of the main drivers of the acceleration in US productivity in the mid-1990s compared to European countries (Van Ark et al., 2008). Management practices greatly affect ICT penetration and exploitation, especially in reference to human resource practices (Bloom et al., 2012). In fact, some studies find that it is not investment in ICT per se that raises productivity but rather its complementarity with changes in the organisation structure and different management practices (Garicano and Heaton, 2010).

Within this literature, the present study is mostly related to Cieslik et al. (2014), who analyse the firm-level determinants of export performance in Central and Eastern European countries using probit regressions on survey data. ${ }^{4}$ These authors also confirm the importance of firm characteristics, with firm size, productivity, human capital and the internationalization of firms all positively related to the probability of exporting. The use of survey information to study productivity bears similarity to the EFIGE-type survey, documented in Altomonte and Aquilante (2012), which focuses on the international operations of firms but also contains a broad range of variables on various areas of firms' activities.

\section{The survey}

The analysis is based on a survey conducted by the Central Bank of Malta in 2014 that was designed in close collaboration with other EU central banks as part of the WDN project for the reference period between 2010 and 2013. The survey focused on changes in the economic environment after the crisis as well as various pricing and wage setting practices. It also contained questions both on developments in labour productivity as well as on a number of covariates that can be proxied for some of the main drivers of productivity identified in the literature.

A total of 271 companies were selected from the Business Register of the National Statistical Office to participate in the survey. Companies were selected to ensure a stratified sectoral representation in three employment brackets: 10-49, 50-199 and those with more than 200 employees. Firms with less than ten employees, public corporations and those operating in the agriculture and fisheries sectors were excluded. Firms falling within the top decile of

\footnotetext{
${ }^{4}$ Cieslik et al. (2004) use the BEEPS (Business Environment and Enterprise Performance Survey) dataset, collected by the EBRD and World Bank in the post-communist countries located in Europe and Central Asia. The objective of this survey is to examine the quality of the business environment and the interactions between private sector firms and the state.
} 
each sector by employment were included since these capture the main developments in the labour market. The fieldwork lasted from May till July 2014 and was carried out using faceto-face interviews. A detailed description of the design of the survey and its sector characteristics is available in Micallef and Caruana (2015).

Throughout the rest of the paper, the results are aggregated in five different sectors: manufacturing, construction, wholesale and retail trade, the financial sector and the rest of the services sector (henceforth, 'other market services'). The latter category is very heterogeneous and includes both traditional industries, such as tourism, as well some of the new industries like computing, professional services and remote gaming.

Table 1 describes the sectoral coverage and the response rate. 178 companies agreed to participate in the survey, implying an overall response rate of $66 \%$. These firms employ around one-third of the target population, with coverage being strongest in the financial sector and manufacturing. Weights were assigned to each company to gross up the survey microdata to the population aggregates. Unless stated otherwise, the results are grossed up using weights based on employment.

Table 1. Sample response rate and employment coverage

\begin{tabular}{l|rrr|rrr}
\hline & \multicolumn{3}{|c|}{ Firms } & \multicolumn{3}{c}{ Employment } \\
& Sample & Response & $\begin{array}{r}\text { Response } \\
\text { Rate (\%) }\end{array}$ & Population & Response & $\begin{array}{c}\text { Coverage } \\
(\%)\end{array}$ \\
\hline Manufacturing & 51 & 32 & 62,7 & 17324 & 7395 & 42,7 \\
Construction & 20 & 9 & 45,0 & 5154 & 1505 & 29,2 \\
Wholesale \& retail trade & 40 & 26 & 65,0 & 14540 & 1893 & 13,0 \\
Financial services & 30 & 24 & 80,0 & 7762 & 5880 & 75,8 \\
Other market services & 130 & 87 & 66,9 & 46783 & 13719 & 29,3 \\
\hline Total & $\mathbf{2 7 1}$ & $\mathbf{1 7 8}$ & $\mathbf{6 5 , 7}$ & $\mathbf{9 1 5 6 3}$ & $\mathbf{3 0 3 9 2}$ & $\mathbf{3 3 , 2}$ \\
\hline
\end{tabular}

Source: Central Bank of Malta and National Statistics Office.

Appendix A provides additional information on the characteristics of the firms and on some of the covariates that will be used in the next section's empirical analysis. As expected, one notes a high degree of heterogeneity at a sectoral level. For instance, firms in construction and wholesale \& retail trade are mostly domestically-oriented whereas around $70 \%$ of sales in manufacturing are generated abroad. The share of labour in total costs is the highest in services and the lowest in manufacturing. Employees covered by a collective agreement are mainly concentrated in manufacturing and the financial sector. A significant percentage of firms in construction and in the financial sector have outsourced part of their operations during the reference period.

A large majority of firms reported an increase in labour costs and base wages during the reference period. To a certain extent, the increase in base wages reflects the institutional features of the Maltese labour market, with the partial adjustment of wages to past inflation through the Cost of Living Adjustment (COLA) mechanism. ${ }^{5}$ However, higher labour costs are also reflective of the buoyant labour market. All sectors reported an increase in both

\footnotetext{
${ }^{5}$ COLA is calculated as the 12-month moving average inflation rate measured from the Retail Price Index (RPI) as at September multiplied by the base wage. The base wage represents a wage level determined in 1990, which has been updated annually by the COLA increases awarded. Annual COLA increases are calculated as a fixed amount that is granted irrespective of the wage level. The base wage on which COLA is calculated is relatively low, standing at around $60 \%$ of the average gross weekly salary.
} 
permanent and temporary employment, as well as in the number of hours worked, with the exception of manufacturing.

\section{Productivity and its determinants}

In addition to questions on labour costs, firms were asked the following question on developments in productivity: "How did average productivity per employee (compared to labour costs per employee) evolve in your firm during 2010-2013?" Respondents were asked to choose from the options 'strong decrease', 'moderate decrease', 'unchanged', 'moderate increase' and 'strong increase'. Chart 1 plots the replies, weighted by employment and grouped into five sectors and three different size classes.

Around $33 \%$ of firms reported that growth in labour productivity exceeded labour costs during the reference period. Another 55\% claimed unchanged developments. This implies that for almost $90 \%$ of firms the increases in labour costs were matched or even exceeded by gains in labour productivity. Improvements in productivity were especially pronounced in manufacturing and, to a lesser extent, in other market services, being reported by around $60 \%$ and $35 \%$ of firms, respectively. In terms of size classes, the improvements in productivity were slightly more pronounced in medium and large firms compared to smaller ones.

These results are at odds with official statistics that point to a sharp deterioration in labour productivity after the crisis. To a certain extent, this could be due to the difficulty of accurately measuring output in an increasingly service-oriented economy. However, it could also be affected by the fact that, by design, micro enterprises, which generally exhibit lower productivity levels compared to larger firms, are excluded from the survey.

Beyond these descriptive statistics, the structural determinants of higher productivity are further investigated within an empirical multivariate framework. More specifically, the analysis is conducted using a probit model with the dependent variable being a binary variable that takes the value of 1 if the firm has registered a 'moderate' or 'strong' increase in productivity compared to labour costs between 2010-2013 and zero otherwise.

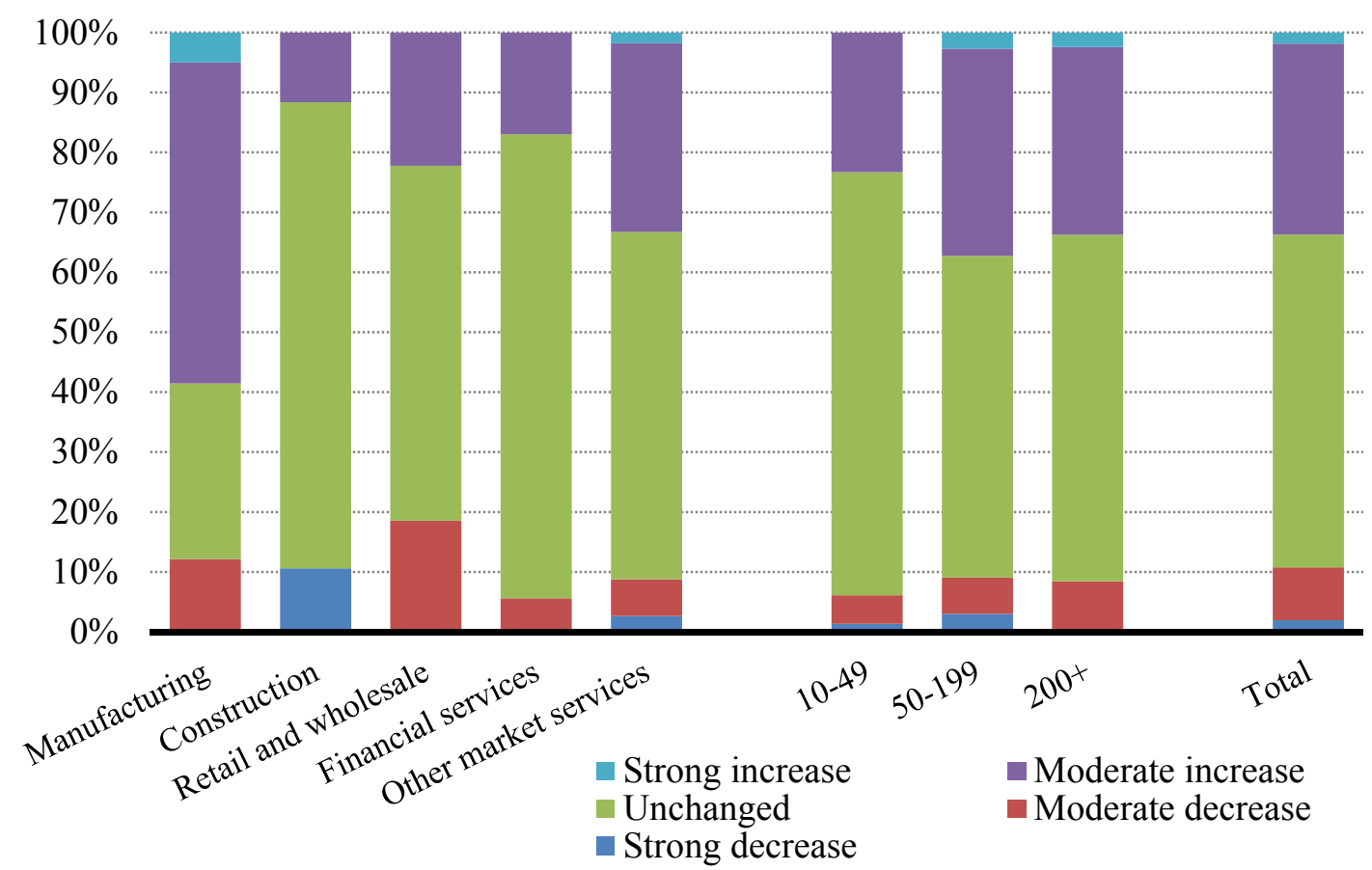

Chart 1. Average productivity compared to costs (percent; weighted by employment)

Source: Author's calculations. 
The probability of a firm registering an increase in productivity during this period is conditioned on a set of covariates that aim to capture the main determinants of productivity identified in the literature. The covariates controls for firm-specific characteristics (e.g. size and sector of economic activity), its production technology, the characteristics of the workforce, the degree of competition faced by the firm, restructuring efforts and the ownership structure of the firm. All these factors were found to play a potentially important role for productivity. To a large extent, however, the list of covariates is dictated by the scope of the questionnaire. For example, no questions were asked on the whether the firm invested in R\&D or introduced any innovative products during the reference period. In another specification, we also account for the nature of the shocks hitting the firm, making a distinction between four different shocks: demand, uncertainty, credit constraints and supply.

More specifically, the exact definition of the covariates is the following:

1. Firm characteristics: a set of variables that capture the sector of economic activity (manufacturing, construction, wholesale \& retail trade and other services) and the size of the firm in terms of number of employees (10-49, 50-199, 200+).

2. Labour share: the share of labour costs (e.g. wages, salaries, bonuses, social security contributions) in total costs (a continuous variable ranging from 0 to 1 ).

3. Workforce characteristics: the share of high-skilled manual and non-manual workers; and the share of part-time and temporary employees in total employment (continuous variables ranging from 0 to 1 ).

4. Workforce stability: a dummy variable that takes the value of 1 if worker flows (both entries and exits) decreased 'strongly' or 'moderately' in 2013 compared to 2010.

5. Outsourcing: a dummy variable that takes the value of 1 for firms that have outsourced part of their activity during 2010-2013.

6. Adjusted labour input: a dummy variable that takes the value of 1 for firms that needed to significantly reduce their labour input or alter its composition during 20102013.

7. Exposure to foreign markets: the share of revenue generated by the firm in foreign markets (continuous variable ranging from 0 to 1 ).

8. Shocks: a set of dummy variables that take the value of 1 for firms that reported a 'strong' or 'moderate' decrease in demand (demand shock), access to external finance (credit constraint shock) and availability of supplies from usual suppliers (supply shock); or a 'strong' or 'moderate' increase in uncertainty (uncertainty shock).

Table 2 reports the average marginal effects from the probit regressions. ${ }^{6}$

Estimates in Model (1) point to some degree of sectoral heterogeneity, with construction firms less likely to benefit from higher productivity compared to the manufacturing sector (the reference category). On the contrary, there is no statistically significant difference between productivity in manufacturing and services. Differences between these two sectors are however captured by the labour share, which is twice as high in services compared to manufacturing. The results show that labour productivity is more likely to be lower in firms with a higher share of labour in total costs. This finding confirms that the significant shift towards services observed in recent years, which are typically more labour intensive, is likely to be an important driver behind the slowdown in domestic labour productivity.

\footnotetext{
${ }^{6}$ It is common practice in the empirical literature using probit models to retain covariates in the model that are recommended by theory or used in similar studies despite not being statistically different from zero. The bottom rows of Table 2 show the Likelihood ratio test. In all models, the hypothesis that all coefficients are equal to zero can be rejected at the 1\% level of significance. Models (3) and (5) in Table 2 show that the results are very robust to the exclusion of non-statistically significant variables.
} 
Differences due to size classes are not statistically significant. This finding runs contrary to what is usually found in the micro literature and could be due to the exclusion of micro companies from the survey. The latter constitute more than $95 \%$ of firms in Malta, accounting for around one third of employment and one quarter of value added. The exclusion of these companies, which are usually less productive than larger firms, could thus explain this counterintuitive result.

The characteristics of the workforce matter for productivity. Workforce stability and a higher share of skilled workers increase the likelihood that a firm reports to have registered an increase labour productivity. Skilled manual workers are found to have a greater and more statistically significant effect compared to skilled non-manual workers. On the contrary, the share of part-timers and temporary employees is negatively related with productivity, although this effect is not statistically significant at conventional levels.

Table 2. Determinants of firm level productivity

Average Marginal Effects

Probit Probit Probit Ordered Probit Ordered Probit

(1)

(2) (3)

(3) (4)

(5)

\begin{tabular}{|c|c|c|c|c|c|}
\hline \multicolumn{6}{|l|}{ Firm size } \\
\hline \multicolumn{6}{|l|}{ 10-49 (Reference group) } \\
\hline $50-199$ & 0,082 & 0,066 & & 0,026 & \\
\hline $200+$ & 0,055 & 0,034 & & $-0,010$ & \\
\hline \multicolumn{6}{|l|}{ Sector of economic activity } \\
\hline \multicolumn{6}{|l|}{ Manufacturing (Reference group) } \\
\hline Construction & $-0,465 * *$ & $-0,468 * *$ & $-0,512 * * *$ & $-0,310 *$ & $-0,342 * *$ \\
\hline Trade & $-0,054$ & $-0,099$ & $-0,135$ & $-0,168$ & $-0,261 * *$ \\
\hline Other market services & 0,060 & 0,001 & $-0,011$ & $-0,008$ & $-0,094$ \\
\hline \multicolumn{6}{|l|}{$\begin{array}{l}\text { Production technology \& workforce } \\
\text { characteristics }\end{array}$} \\
\hline Share of labour in total costs & $-0,387 * *$ & $-0,378 * *$ & $-0,414 * *$ & $-0,508 * * *$ & $-0,545 * * *$ \\
\hline Workforce stability & $0,194 * *$ & $0,239 * * *$ & $0,230 * * *$ & $0,177 *$ & $0,207 * *$ \\
\hline Share of part-timers and temporary worl & $-0,161$ & $-0,173$ & & $-0,150$ & \\
\hline Share of high skilled manual workers & $0,303 * *$ & $0,251 *$ & $0,229 *$ & 0,173 & \\
\hline Share of high skilled non-manual worker & 0,060 & 0,048 & & 0,090 & \\
\hline \multicolumn{6}{|c|}{ Restructuring, firm structure \& competition } \\
\hline Outsourcing & $0,162 * *$ & $0,149 * *$ & $0,166 * *$ & $0,154 * *$ & $0,158 * *$ \\
\hline Labour force adjustment & 0,042 & 0,101 & & 0,127 & \\
\hline Exposure to foreign markets & 0,013 & 0,038 & & 0,001 & \\
\hline \multicolumn{6}{|l|}{ Nature of shocks } \\
\hline Demand shock & & $-0,108$ & & $-0,210 * *$ & $-0,180 * *$ \\
\hline Uncertainty shock & & $-0,057$ & & $-0,073$ & \\
\hline Credit constraint shock & & $-0,359 *$ & $-0,343 *$ & $-0,310 * *$ & $-0,301 * *$ \\
\hline Supply shock & & $-0,109$ & & $-0,107$ & \\
\hline Observations & 177 & 177 & 177 & 177 & 177 \\
\hline Likelihood ratio test & $\chi 2(13)=35.77$ & $\chi 2(17)=41.52$ & $\chi 2(8)=36.57$ & $\chi 2(17)=38.81$ & $\chi 2(8)=33.73$ \\
\hline Prob $>\chi 2$ & 0,001 & 0,001 & 0,000 & 0,002 & 0,000 \\
\hline Pseudo R2 & 0,1578 & 0,1832 & 0,161 & 0,1163 & 0,1011 \\
\hline
\end{tabular}

Note: $* * *, * * \& *$ denote statistical significance at $1 \%, 5 \%$ and $10 \%$, respectively

In Probit models (1), (2) and (3), the dependent variable is a dummy that takes the value of 1 if the firm reported a 'moderate' or 'strong' increase in productivity compared to labour costs. In ordered probit (4), the dependent variable is a categorical variable that takes the value of 1 if productivity decreased, 2 if unchanged and 3 if productivity increased relative to labour costs. Column 5 reports the AME of outcome 3 (i.e. increase in productivity) to be comparable with Models (1) and (2). Model (5) re-estimates Model (4) using only statistically significant variables. 
Restructuring efforts are found to increase the likelihood of higher productivity. Firms that have implemented changes to their production structure, for instance, by outsourcing part of their operations, are more likely to experience an improvement in productivity. Companies that adjusted their labour force or exposed to foreign markets are also likely to report an improvement in productivity although, in both cases, the effects are not statistically significant.

Model (2) augments the covariates in the previous model with the nature of the shocks hitting the firm. Out of the four adverse shocks considered - a drop in demand, higher uncertainty, a reduction in the access to finance and in the availability of supplies - firms faced with credit constraints were found to be less likely to experience an improvement in productivity. This finding suggests that credit impairments, not only via the quantity but perhaps also its price, could provide another important channel through which the financial sector affects labour productivity. ${ }^{7}$ Model (3) includes only those covariates that were statistically significant in the previous two models. The marginal effects of the statistically significant variables are very similar to those reported in Models (1) and (2).

To assess the robustness of the results, Model (4) presents the estimates of an ordered probit approach. This time, the dependent variable, instead of a binary $0-1$ variable, is a categorical one that increases with productivity, taking values from 1 to 3 , where $1=$ the firm reported a 'moderate decrease' or 'strong decrease' in productivity; $2=$ the firm reported 'unchanged' productivity; $3=$ the firm reported a 'moderate increase' or 'strong increase' in productivity. Table 2 reports the average marginal effects of category 3 - an increase in productivity - to make it comparable to the first two columns. Model (5) is estimated using only the statistically significant covariates of Model (4).

The main conclusions remain unchanged with three differences. First, the share of high skilled manual workers no longer remains statistically significant. Second, sectoral heterogeneity becomes more pronounced, with both construction and trade less likely to benefit from higher labour productivity compared to the manufacturing sector. Finally, demand shocks also turn out to be important, with firms facing adverse demand shocks less likely to register an improvement in productivity. This could be due, for instance, to labour hoarding as firms may prefer to retain workers rather than incur hiring and retraining costs when demand conditions return to normal. As in Model (3), the ordered probit model confirms the negative relationship between credit constrained firms and productivity, as well as the role played by the declining share of labour, workforce stability and outsourcing.

\section{Discussion and policy recommendations}

In the decade since EU membership in 2004, Malta registered the highest increase in the share of services in gross value added among EU countries, while, at the same time, the share of industry declined from $28 \%$ to $17 \%$ (Grech, 2015). The results suggest that the changing structure of the Maltese economy, with the expansion of very labour-intensive services, played an important role in the economy's labour productivity decline in recent years. This finding, which is robust to various model specifications, complicates the use and reliance on aggregate unit labour costs as a measure of competitiveness. Sectoral estimates of hourly labour costs suggest that Malta remains quite competitive compared to other euro area countries in terms of costs and has even maintained its cost competitiveness despite the reduction in labour costs in a number of stressed economies since the financial crisis (Micallef, 2015).

\footnotetext{
${ }^{7}$ Micallef and Gauci (2014) document a decline in interest rate pass-through for domestic NFCs after the crisis.
} 
Another interesting finding is the relationship between productivity and outsourcing. The latter has been on the rise in recent years, spanning both IT and non-IT activities, such as security and cleaning activities. Productivity benefits from outsourcing as the firm reorganises its production activities. However, it also calls for caution in the interpretation of the decline in the share of certain sectors, such as manufacturing, since a considerable proportion could be the result of outsourcing of certain tasks.

The results confirm the importance of skills and workforce stability to foster productivity growth. The positive relationship between employment stability and productivity is very robust across model specifications. Employment stability or tenure increases the gains of learning-by-doing and provides incentives for employers to invest in training since they will be reaping the rewards of their investment. More generally, these findings support policies that raise the workforce's skill base, not only through investment in education but also to strengthen active labour market policies, such as lifelong learning and the provision of adequate incentives, for both employers and employees, that promotes the development of job-specific skills.

The negative relationship between productivity and credit constrained firms calls for policies that improve access to credit, especially for SMEs. In this regard, judicial reforms that reduce the time required to recover collateral and the planned introduction of a credit registry should improve both the access and the cost of credit by reducing informational asymmetries and the risk premium charged by banks. The introduction of a development bank should also facilitate SME financing and lower the cost of credit.

Firms facing adverse demand conditions are less likely to register improvements in productivity although this finding is not robust across all model specifications. To an extent, this could be due to labour hoarding, especially if disturbances are deemed to be transitory. However, it strengthens the need for prudent fiscal policy in good times, thereby allowing room for manoeuvre during periods of subdued demand to stimulate economic activity and productivity.

\section{Conclusion}

Despite its robust economic performance, labour productivity in Malta has been sluggish after the crisis, underperforming most other European economies. This study attempts to by-pass severe data limitations by exploiting information from a unique firm-level survey carried out by the Central Bank of Malta in 2014 as part of the WDN project. The structural determinants of productivity are investigated within an empirical multivariate framework that controls for various characteristics, both within and outside the firm.

The results suggest that the shift towards labour intensive services experienced since EU membership is likely to be an important driver behind the slowdown in productivity. Outsourcing and workforce characteristics are also found to be important determinants. Credit constrained firms and those hit by adverse demand conditions are less likely to experience an improvement in productivity.

A caveat is in order in the interpretation of the results. While the survey is representative of the target population, it excludes micro companies with less than 10 employees. Since micro companies account for around one third of employment in Malta, more effort should be devoted in the future to better understand the drivers of productivity in this category of firms. Another limitation is that the choice of the covariates used in this study was limited to the information contained in the survey, which was not originally intended to address issues related to productivity. Hence, the role of factors such as investment in ICT, R\&D, foreign direct investment (FDI) or changes in management practices could not be addressed. 
Going forward, analysis of Malta's productivity should focus more on sectoral trends and, increasingly, on firm-level developments, rather than on economy-wide aggregate measures. This granular detail requires an improvement in the quality and availability of statistics. Dedicated surveys of firms, possibly covering also micro companies, can be used to shed further light on other important determinants of productivity. An increasingly popular approach in this area is to match micro-based national statistics with survey information or other databases, such as firms' balance sheets. In this regard, an interesting avenue for future research should focus on better understanding the relationship between productivity, investment, financing conditions, firm size and export performance.

\section{Acknowledgements}

The author is grateful to Aaron $G$ Grech and an anonymous referee for helpful comments and suggestions. Any errors, as well as the views expressed in this article, are the author's sole responsibility. The views expressed in this paper are those of the author and should not be interpreted as reflecting the views of the Central Bank of Malta.

\section{References}

Altomonte, G., Barba Naveretti, G., Di Mauro, F. and Ottaviano, G. (2011), Assessing competitiveness: how firm-level data can help, Bruegel Policy Contribution, 2011/16.

Altomonte, C. and Aquilante, T. (2012), The EU-EFIGE/Bruegel-Unicredit dataset, Bruegel Working Paper 2012/13.

Barro, R. (2001), Human capital and growth, American Economic Review 91, No. 2 (May), pp. 12-17.

Barro, R. and Sala-i-Martin, M. (2004), Economic Growth, MIT press, Second Edition.

Bartelsman, E. and Doms, M. (2000), Understanding Productivity: Lessons from Longitudinal Microdata, Journal of Economic Literature, 38(3), pp. 569-594.

Bartelsman, E. (2013), ICT, reallocation and productivity, European Economy Economic Papers 486.

Bartelsman, E., Haltiwanger, J. and Scarpetta, S. (2013), Cross-country differences in productivity: the role of allocation and selection, American Economic Review, 103 (1), pp. 305-334.

Berthou, A., Dhyne, E. and the CompNet Task Force (2015), Assessing European firms' exports and productivity distributions: the CompNet trade module, European Central Bank Working Paper 1788.

Bloom, N., Sadun, R. and Van Reenen, J. (2012), Americans do IT better: US multinationals and the productivity miracle, American Economic Review, 102 (1), pp. 167-201.

Brynjolfsson, E. and McAfee, A. (2014), The second age machine: work, progress and prosperity in a time of brilliant technologies, New York, W.W Norton \& Company.

Cieslik, A., Michalek, J. and Michalek, A. (2014), Firm level determinants of export performance: evidence from post transition countries, paper presented at the ETSG Annual Conference, September 2014.

Clark, G. (2016), Winter is coming: Robert Gordon and the future of economic growth, American Economic Review, 106 (5), pp. 68-71.

CompNet Task Force (2014), Micro-based evidence of EU competitiveness: the CompNet database, European Central Bank Working Paper 1634.

Demian, C. and di Mauro, F. (2015), The exchange rate, asymmetric shocks and asymmetric distributions, European Central Bank Working Paper 1801. 
Di Mauro, F. and Ronchi, M. (2015), Assessing European competitiveness: the contribution of CompNet research, European Central Bank, CompNet Report, June 2015.

European Commission (2014), The drivers of total factor productivity in catching-up economies, Quarterly Report on the Euro Area, Vol. 13, Issue 1.

Fernald, J. (2012), Productivity and potential output before, during and after the Great Recession, Federal Reserve Bank of San Francisco Working Paper 2012-18.

Ferrando, A., Iudice, M., Altomonte, C., Blank, S., Felt, M.H., Meinen, P., Neugebauer, K. and Siedschlag, I. (2015), Assessing the financial and financing conditions of firms in Europe: the financial module in CompNet, European Central Bank Working Paper 1836.

Ferrando, A. and Ruggieri, A. (2015), Financial constraints and productivity: evidence from euro area companies, European Central Bank Working Paper 1823.

Gamberoni, E., Giordano, C. and Lopez-Garcia, P. (2016), Capital and labour (mis)allocation in the euro area: some stylized facts and possible determinants, European Central Bank Working Paper.

Garicano, L. and Heaton, P. (2010), Information Technology, Organization, and Productivity in the Public Sector: Evidence from Police Departments, Journal of Labour Economics, Vol. 28, No. 1, pp. 167-201.

Gordon, R. (2016), The rise and fall of American growth: the US standard of living since the Civil War, Princeton University Press.

Grech, A. G. (2015), The diversification of the Maltese economy, Central Bank of Malta Policy Note, September 2015.

Grech, A. G. and Micallef, B. (2015), Assessing potential output growth of the Maltese economy using a production function approach, Xjenza, Vol. 3, Issue 1, pp. 57-63.

Griffith, R., Redding, S. and van Reenen, J. (2004), Mapping the two faces of R\&D: productivity growth in a panel of OECD industries, The Review of Economics and Statistics, Vol. 86(4), pp. 883-895.

Hall, R. and Jones, C. (1999), Why do some countries produce so much more output per worker than others? Quarterly Journal of Economics, Vol. 114 (February), pp. 83-116.

Hartmann, P., Heider, F., Papaioannou, E. and Lo Duca, M. (2007), The role of financial markets and innovation in productivity and growth in Europe, European Central Bank Occasional Paper 72.

Krugman, P. (1994), The age of diminished expectations, MIT Press.

Lopez-Garcia, P., di Mauro, F. and the CompNet Task Force (2015), Assessing European competitiveness: the new CompNet micro-based database, European Central Bank Working Paper 1764.

Micallef, B. and Gauci, T. (2014), Interest rate pass-through in Malta, Central Bank of Malta Quarterly Review, 1, pp. 71-82.

Micallef, B. (2015), Sectoral and cross-country estimates of hourly labour costs, Central Bank of Malta Quarterly Review, 2, pp. 56-60.

Micallef, B. and Caruana, K. (2015), Results of the 2014 Wage Dynamics Network for Malta, available:

https://www.ecb.europa.eu/home/pdf/research/wdn/WDN_Country_Report_MT_final.p df?7a1aa775335f737091e097051def82a8.

Nicoletti, G. and Scarpetta, S. (2003), Regulation, productivity and growth: OECD evidence, Economic Policy, April, pp. 9-72.

Romer, P. (1990), Endogenous technological change, Journal of Political Economy, Vol. 96, pp. 71-102.

Solow, R. (1957), Technical change and the aggregate production function, Review of Economics and Statistics, Vol. 39, pp. 313-20. 
Sondermann, D. (2012), Productivity in the euro area: any evidence of convergence? European Central Bank Working Paper No. 1431.

Syverson, C. (2010), What Determines Productivity? Journal of Economic Literature, 49(2), pp. 326-65.

Van Ark, B., O'Mahony, M. and Timmer, M. (2008), The productivity gap between Europe and the US: trends and causes, Journal of Economic Perspectives 22 (1), pp. 25-44. 


\section{Appendix A: Firm characteristics}

The table below provides an overview of selected results and findings from the survey, aggregated in five sectors of economic activity that are used as covariates in the econometric analysis or are deemed relevant for the interpretation of the results (e.g. the broad-based increase in labour costs). Full details of the results are available in Micallef and Caruana (2015).

\section{OVERVIEW OF FIRM CHARACTERISTICS}

(percent)

\begin{tabular}{|c|c|c|c|c|c|}
\hline & Manufacturing & Construction & $\begin{array}{c}\text { Wholesale \& } \\
\text { Retail }\end{array}$ & $\begin{array}{c}\text { Financial } \\
\text { services }\end{array}$ & $\begin{array}{c}\text { Other market } \\
\text { services }\end{array}$ \\
\hline \multicolumn{6}{|l|}{ Ownership of the firm ${ }^{\text {(a) }}$} \\
\hline Mainly domestic & 50.0 & 100.0 & 100.0 & 78.0 & 90.4 \\
\hline Mainly foreign & 50.0 & 0.0 & 0.0 & 22.0 & 9.6 \\
\hline \multicolumn{6}{|l|}{ Workforce characteristics ${ }^{(b)}$} \\
\hline \multicolumn{6}{|l|}{ Skill distribution } \\
\hline Higher skilled non-manual & 15.6 & 13.6 & 17.5 & 45.9 & 35.1 \\
\hline Lower skilled non-manual & 8.8 & 13.5 & 42.4 & 42.2 & 26.1 \\
\hline Higher skilled manual & 62.4 & 59.3 & 17.1 & 5.8 & 13.0 \\
\hline Lower skilled manual & 13.3 & 13.6 & 23.1 & 6.0 & 25.9 \\
\hline \multicolumn{6}{|c|}{ Production techology, foreign exposure \& pay structure ${ }^{(b)}$} \\
\hline Share of labour in total costs & 26.9 & 38.6 & 39.9 & 51.5 & 52.4 \\
\hline Share of employees covered by collective agreement & 51.9 & 8.7 & 8.9 & 40.8 & 14.3 \\
\hline Share of bonuses in total wage bill & 2.5 & 1.0 & 2.9 & 5.3 & 4.3 \\
\hline \multicolumn{6}{|l|}{ Share of revenue generated in: } \\
\hline Domestic market & 29.5 & 97.1 & 97.4 & 65.0 & 51.8 \\
\hline Foreign market & 70.5 & 2.9 & 2.5 & 35.0 & 48.2 \\
\hline Share that outsourced operations & 25.4 & 67.4 & 11.8 & 40.3 & 27.9 \\
\hline \multicolumn{6}{|l|}{ Evolution of labour costs ${ }^{\text {(c) }}$} \\
\hline Labour costs & 75.7 & 100.0 & 68.3 & 24.5 & 89.5 \\
\hline Base wages & 75.8 & 89.4 & 92.2 & 84.6 & 86.4 \\
\hline Flexible wage components & 15.1 & 32.8 & 38.4 & 47.0 & 45.0 \\
\hline Number of permanent employees & -0.9 & 44.7 & 53.9 & 35.5 & 34.8 \\
\hline Number of temporary/fixed-term employees & 12.5 & 11.9 & 16.0 & 46.6 & 29.6 \\
\hline Working hours per employee & -2.9 & 22.5 & 11.5 & 27.9 & 21.4 \\
\hline
\end{tabular}

Note: (a) and (b) denote aggregation using firm and employment weights, respectively.

(c) reports the net percentage change between those that reported an 'increase' and a 'decrease' during the reference period Source: Author's calculations 